\title{
Keefektifan Blended - Problem Based Learning terhadap Pemecahan Masalah pada Materi Ekologi
}

\author{
Elok Dyah Pitaloka ${ }^{1}$, Slamet Suyanto ${ }^{1}$ \\ ${ }^{1}$ Pendidikan Biologi-Universitas Negeri Yogyakarta
}

\begin{tabular}{l}
\hline INFO ARTIKEL \\
\hline Riwayat Artikel: \\
Diterima: 23-04-2019 \\
Disetujui: 27-05-2019 \\
\hline
\end{tabular}

\section{Kata kunci:}

blended-problem based learning; problem solving; ecology;

blended-problem based learning; ekologi;

pemecahan masalah

\begin{abstract}
ABSTRAK
Abstract: Biology learning must utilize technology and direct students to have problem solving skills, so that learning innovations are blended-problem based learning. This study aims to look at the effectiveness of blended-problem based learning on problem solving, when compared to learning that applies the scientific approach (5M). This study categorized as quasi-experimental research, using the design of the pretestposttest control group. The independent t-test obtained the sig value. $0.00<0.05$, so that it can be interpreted that the posttest value of the executive class and control is significantly different. N-Gain score testing was obtained from the 0.70 high category experimental class, while 0.298 for the low category control class. Based on these data, blended-problem based learning can be said to be effective against solving ecological chapter problems.
\end{abstract}

\begin{abstract}
Abstrak: Pembelajaran Biologi harus memanfaatkan teknologi dan mengarahkan peserta didik memiliki kemampuan pemecahan masalah sehingga memunculkan inovasi pembelajaran blended-problem based learning. Penelitian ini bertujuan melihat keefektifan blended-problem based learning pada pemecahan masalah, jika dibandingkan pembelajaran yang menerapkan pendekatan saintifik (5M). Penelitian ini dikategorikan penelitian eksperimen semu menggunakan desain pretest-posttest control group. Uji independent $t$-test memperoleh nilai sig. $0,00<0,05$, sehingga dapat diartikan nilai posttest kelas ekseprimen dan kontrol berbeda signinifikan. Pengujian N-Gain score diperoleh reratal kelas ekspeimen 0,70 kategori tinggi, sedangkan 0,298 untuk kelas kontrol kategori rendah. Berdasarkan data tersebut, blended-problem based learning dapat dikatakan efektif terhadap pemecahan masalah bab ekologi.
\end{abstract}

\author{
Alamat Korespondensi: \\ Elok Dyah Pitaloka \\ Pendidikan Biologi \\ Universitas Negeri Yogyakarta \\ Kampus Karangmalang, Yogyakarta \\ E-mail: elokdyahpitalokaa@gmail.com
}

Pembelajaran pada jenjang Sekolah Menengah Atas mengarahkan peserta didik mencapai ketentuan pembelajaran abad 21. Ketentuan pembelajaran biologi abad ke-21 yaitu membekali peserta didik dengan berbagai keterampilan dan kecakapan seperti communication, collaboraion, critical thinking, creativity, innovation, problem solving, and ICT Literacyn (Trilling \& Fadel, 2009). Kemampuan pemecahan masalah dan keterampilan penggunaan TIK harus dimiliki peserta didik. Keterampilan penggunaan TIK dapat dimiliki peserta didik melalui penggunaan teknologi dalam pembelajaran Biologi. Penggunaaan teknologi yang telah dibuat secara khusus untuk digunakaan dalam pembelajaran dapat menjadikan pembelajaran Biologi menjadi efektif, menciptakan lingkungan belajar student centered dan membantu peserta didik menguasai aspek kognitifnya (Smaldino, Lowther, \& Mims, 2012). Selain itu, penggunaan teknologi dan internet dalam pembelajaran biologi memberikan kebebasan dalam mencari bahan materi yang mendukung materi pembelajaran (Torres-Gastelú, Dominguez, García, Kiss, \& Espinoza, 2015).

Perkembangan teknologi dan pemanfaatan internet dalam dunia pendidikan memunculkan adanya e-learning. Elearning merupakan sistem pembelajaran online yang menggunakan platfrom online tanpa adanya pembelajaran tatap muka di kelas. Pembelajaran e-learning mengharuskan peserta didik belajar secara mandiri sesuai dengan petunjuk yang telah disediakan oleh guru pada platform online. Pembelajaran e-learning memberikan kemudahan peserta didik untuk belajar kapanpun, dimanapun, dan dalam kondisi kapanpun selama terkoneksi dengan jaringan internet (Holmes \& Prieto-Rodriguez, 2018; Ramakrisnan, Yahya, Hasrol, \& Aziz, 2012). Namun, pembelajaran Biologi pada jenjang SMA membutuhkan tatap muka dalam pembelajaran di kelas. Maka, diperlukan pembelajaran e-learning (pembelajaran online) dan pembelajaran tatap muka (pembelajaran konvensional). Pembelajaran semacam ini dikenal dengan blended learning (Ghavifekr \& Rosdy, 2016; Ju \& Mei, 2018; Pulham \& Graham, 2018). 
Penerapan blended learning dalam pembelajaran Biologi memberikan kemudahan mengakses dan mempelajari materi biologi yang disajikan oleh guru untuk peserta didik pada pembelajaran online dengan bebas, tidak dibatasi oleh waktu dan tempat (Means, Toyama, Murphy, \& Baki, 2013). Selain itu, penerapan blended learning dalam pembelajaran Biologi memberikan peluang peserta didik berdiskusi dengan peserta didik lain dan guru melalui pembelajaran online maupun pembelajaran secara langsung di kelas. Kegiatan belajar online dalam penerapan blended learning tetap diawasi oleh guru (Suryani, 2013). Penerapan blended learning dalam pembelajaran Biologi dapat memenuhi keterampilan peserta didik berupa keterampilan penggunaan TIK dan kemampuan pemecahan masalah. Kemampuan pemecahan termasuk ke dalam berpikir Higher Order Thinking Skill yang harus dimiliki peserta didik karena menjadikan peserta didik mampu memecahkan masalah dalam kehidupan dan membuat peserta didik mampu menentukan keputusan yang tepat. Pembelajaran Biologi berkaitan dengan alam, makhluk hidup dan kehidupan manusia sehingga banyak permasalahan yang dapat diangkat ke dalam pembelajaran. Apalagi, materi ekologi yang berkaitan dengan makhluk hidup dan lingkungannya, maka pada pembahasan materi ekologi banyak permasalahan yang dapat dikaji dalam proses pembelajaran Biologi.

Penerapan blended learning dalam pembelajaran Biologi perlu untuk diintegrasikan dengan model pembelajaran saintifik yang dianjurkan pada K-13. Model pembelajaran saintifik yang cocok untuk diintegrasikan dengan blended learning, salah satunya yaitu problem based learning, karena implementasi blended learning dan problem based learning sama-sama menggunakan teori konstruktivisme (Al-Huneidi \& Schreurs, 2013). Implementasi problem based learning memakai stimulus berupa permasalahan yang ada di lingkungan peserta didik (Aziz, Zain, Samsudin, \& Saleh, 2014; Etherington, 2011; Magdalena, Mulyani, \& Susanti, 2014; Pourshafie \& Murray-Harvey, 2013), dan penerapan problem based learning membutuhkan waktu yang tidak sedikit (Gündüz, Alemdağ, Yaşar, \& Erdem, 2016; Selvi, Kaleel, \& Chinnaiah, 2012). Namun, hal ini dapat diatasi dengan pembelajaran online dalam penerapan blended learning. Penerapan blended learning dengan problem based learning disebut blended-problem based learning, maksudnya adalah kegiatan belajar-mengajar biologi yang prosesnya memakai sintaks atau langkah-langkah problem based learning. Kemudian, dari tahapan (sintaks) problem based learning terdapat tahap problem based learning yang dilaksanakan melalui pembelajaran online dan terdapat langkah problem based learning yang dilaksanakan melalui pembelajaran langsung. Menurut Delialioğlu (2012), Blended Learning dengan problem based learning saling mendukung dalam kegiatan belajar-mengajar tatap muka maupun kegiatan belajar online.

Kegiatan belajar online (e-learning) dalam blended-problem based learning menggunakan Learning Management System (LMS) untuk menyajikan informasi, mengelola materi pembelajaran, dan mengevaluasi peserta didik (Ghazal, Aldowah, \& Umar, 2018). Learning Management System (LMS) yang digunakan yaitu quipper school. Kegiatan pembelajaran online yang dilakukan peserta didik di quipper school yaitu peserta didik mempelajari materi, mendownload materi, mengerjakan quiz dan melakukan diskusi online. Adanya diskusi online dalam pembelajaran online memberikan kebebasan kepada peserta didik untuk mengajukan, menanggapi masalah dan mendukung peserta didik memperoleh informasi yang lebih luas terkait materi (Isman, Abanmy, Hussein, \& Al Saadany, 2012). Implementasi blended-problem based learning dalam kegiatan belajarmengajar biologi efektif terhadap pemecahan masalah. Pernyataan ini sesuai dengan beberapa penelitian, seperti penelitian Şendağ \& Odabaşi (2009), menyimpulkan blended-problem based learning signifikan dalam meningkatkan high order thinking skills dan pemecahan masalah termasuk ke dalam high order thinking skills. Penelitian Yeh (2010), mengungkapkan interaksi blended learning dengan problem based learning dalam kegiatan belajar-mengajar meningkatkan keterampilan kognitif tingkat tinggi termasuk pemecahan masalah.

Berdasarkan penjabaran tersebut, untuk melihat keefektifan blended-problem based learning perlu dilakukan penelitian terkait keefektifan blended-problem based learning terhadap pemecahan masalah pada bab ekologi di SMA N 5 Yogyakarta. Penelitian ini bertujuan melihat keefektifan blended-problem based learning terhadap pemecahan masalah peserta didik pada bab ekologi. Keefektifan blended-problem based learning dilihat berdasarkan perhitungan nilai rerata N-Gain score, jika rerata $\mathrm{N}-$ Gain score eksperimen lebih tinggi daripada kontrol maka blended-problem based learning dikatakan efektif.

\section{METODE}

Jenis penelitian ini merupakan eksperimen semu yang menggunakan desain pretest-posttest control group. Peserta didik kelas X MIPA di SMAN 5 Yogyakarta tahun ajaran 2018/2019 merupakan populasi dalam penelitian ini. Kemudian, diambil sampel yang akan digunakan sebagai sampel penelitian dengan teknik cluster random sampling. Sampel tersebut, yaitu X MIPA 4 terdiri dari 30 peserta didik dijadikan kelas eksperimen yang dalam kegiatan belajar-mengajarnya menerapkan blended-problem based learning dan X MIPA 3 terdiri dari 28 peserta didik dijadikani kelas kontrol yang dalam kegiatan belajar-mengajarnya menerapkan pendekatan saintifik $(5 \mathrm{M})$.

Perangkat pembelajaran seperti instrumen tes, quipper school, LKPD, RPP, dan silabus digunakan sebagai instrumen pada penelitian. Perangkat pembelajaran telah divalidasi oleh dosen ahli (expert judgement). Instrumen tes berupa instrumen tes pemecahan masalah terdiri dari enam soal uraian. Uji validitas dan reabilitas dilakukan untuk menguji kelayakan instrumen tes pemecahan masalah yang terdiri dari validitas isi dan konstruk oleh dosen ahli, serta validitas emprisi yang dihitung menggunakan SPSS 15. Uji reabilitas menggunakan alpha cronbach taraf sig 5\% melalui SPSS 15. 
Soal pemecahan masalah diteskan kepada peserta didik pada kelas eksperimen dan kelas kontrol sebelum pembelajaran materi ekologi dimulai (pretest) dan setelah pembelajaran pada materi ekologi selesai diajarkan (posttest). Data nilai pretest dan posttest pemecahan masalah dihitung melalui statistik deskriptif dan statistik inferensial. Hasil data statistik deskriptif ditunjukan dengan grafik dan tabel. Hasil analisis statistik inferensial disajikan dalam bentuk uji prasyarat, kemudian dilanjutkan pengujian hipotesis menggunakan program SPSS 15. Uji normalitas dan homogenitas dilakukan terlebih dahulu sebagai uji prasyarat untuk menghitung data kuantitatif nilai pretest dan posttest pemecahan masalah. Apabila Uji prasyarat terpenuhi (data normal dan homogen), dilanjutkan uji hipotesis secara parametrik dengan uji independent $t$-test dan $\mathrm{N}$-Gain. Pengujian ini dilakukan untuk mengetahui keefektifan blended-problem based learning terhadap pemecahan masalah.

\section{HASIL}

Analisis pemecahan masalah diawali dengan analisis deskriptif untuk mendeskripsikan kemampuan peserta didik dalam memecahkan masalah sebelum dan sesudah diberikan perlakuan. Nilai pretest pada kelas eksperimen dan kontrol digunakan untuk mengetahui kemempuan awal pemecahan masalah peserta didik sebelum diberikan perlakuan. Sedangkan, nilai posttest kelas eksperimen dan kelas kontrol digunakan untuk mengetahui kemampuan kemampuan pemecahan masalah peserta didik setelah diberi perlakuan. Hasil nilai pretest dan posttest dapat dilihat pada tabel 1.

Tabel 1. Nilai Prestest dan Posttest Pemecahan Masalah

\begin{tabular}{lcccc}
\hline \multirow{2}{*}{ Deskripsi } & \multicolumn{2}{c}{ Nilai Pretest } & \multicolumn{2}{c}{ Nilai Posttest } \\
& (Kemampuan Awal Pemecahan Masalah) & (Kemampuan Akhir Pemecahan Masalah) \\
\cline { 2 - 5 } & Kelas Eksperimen & Kelas Kontrol & Kelas Eksperimen & Kelas Kontrol \\
\hline Jumlah Peseta Didik & 30 & 28 & 30 & 28 \\
\hline Nilai Maksimum & 58,33 & 58,33 & 100,00 & 75,00 \\
\hline Nilai Minimum & 16,67 & 12,50 & 54,17 & 33,33 \\
\hline Simpangan Baku & 10,59 & 10,83 & 13,10 & 11,84 \\
\hline Rata-rata & 35,56 & 35,86 & 80,00 & 54,91 \\
\hline
\end{tabular}

Hasil analisis pada tabel 1, rerata kemampuan awal (pretest) pemecahan masalah kelas eksperimen 35,56 dan rerata pretest kelas kontrol 35,86. Berdasarkan data tersebut dapat dikatakan kelas eksperimen dan kontrol mempunyai kemampuan awal yang hampir setara dengan selisih 0,30. Perbedaan rerata pretest kelas eksperimen dan kontrol diuji menggunakan program SPSS 15 dihasilkan nilai sig. 0,91 (nilai sig>0,05), sehingga $H_{o}$ diterima dan $H_{a}$ ditolak artinya tidak terdapat perbedaan antara kemampuan pemecahan masalah awal dan akhir peserta didik pada kelas eksperimen dan kontrol. Jadi, kelas eksperimen dan kelas kontrol memenuhi syarat untuk digunakan penelitian. Hasil pengujian disajikan pada tabel 2.

Tabel 2. Perhitungan Nilai Rerata Pretest Pemecahan Masalah Kelas Eksperimen dan Kontrol

\begin{tabular}{cccc}
\hline Jenis Data & Nilai sig. & $\boldsymbol{\alpha}$ & Keterangan \\
\hline Pretest & 0,91 & 0,05 & $\begin{array}{c}\mathrm{H}_{\mathrm{o}} \text { diterima } \\
\text { Tidak terdapat perbedaan }\end{array}$ \\
\hline
\end{tabular}

Tabel 1 menunjukkan nilai rerata kemampuan akhir (posttest) pemecahan masalah kelas eksperimen (blended-problem based learning) memperoleh hasil 80,00 sedangkan nilai rerata posttest (pendekatan saintifik 5M) sebesar 54,91. Hal ini menunjukan ke dua kelas tersebut memiliki kemempuan akhir pemecahan masalah yang berbeda dengan selisih 25,09 dan rerata posttest pada kelas kontrol lebih rendah dibandingkan kelas eksperiemen yang menerapkan blended-problem based learning. Untuk mengetahui secara jelas perbedaan rerata pretest dan posttest ke dua kelas tersebut, dapat dilihat pada gambar 1 . Uji prasyarat terpenuhi jika data mempunyai kelompok yang homogen dan normal. Hasil pengujian prasyarat meliputi pengujian normalitas dan homogenitas. Pengujian normalitas disajikan pada tabel 3 dan 4.

Tabel 3. Hasil Pengujian Normalitas Kemampuan Pemecahan Masalah

\begin{tabular}{clccc}
\hline \multirow{2}{*}{ Jenis Data } & \multirow{2}{*}{ Kelas } & \multicolumn{3}{c}{ Kolmogorov-Smirnov } \\
\cline { 3 - 5 } & & Statistic & df & Sig. \\
\hline \multirow{2}{*}{ Pretest } & Eksperimen & 0,13 & 30 & $0,200^{*}$ \\
\cline { 2 - 5 } & Kontrol & 0,97 & 28 & $0,200^{*}$ \\
\hline \multirow{2}{*}{ Posttest } & Eksperimen & 0,12 & 30 & $0,200^{*}$ \\
\cline { 2 - 5 } & Kontrol & 0,90 & 28 & $0,200^{*}$ \\
\hline
\end{tabular}


Tabel 3 menunjukkan hasil analisis pretest dan posttest yang memperoleh nilai sig.>0,05. Data dikatakan normal, jika nilai sig. hasil analisis lebih besar dari 0,05 maka data-data pada penelitian ini dikatakan normal.

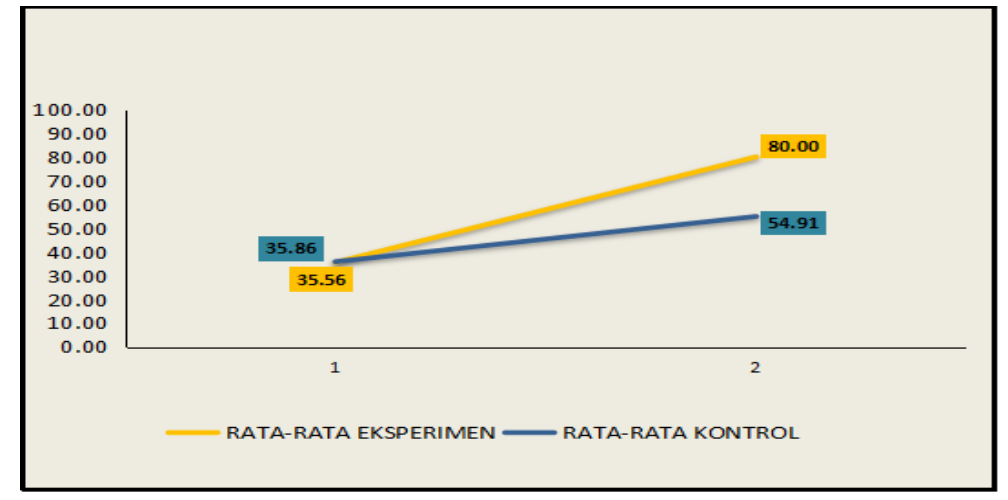

Gambar 1. Grafik Nilai Rerata Pretes dan Posttest

Tabel 4. Hasil Pengujian Homogenitas Kemampuan Pemecahan Masalah

\begin{tabular}{ccccc}
\hline Jenis Data & Levene Statistic & df1 & df2 & Sig. \\
\hline Pretest & 0,00 & 1 & 56 & 0,99 \\
\hline Posttest & 0,38 & 1 & 56 & 0,54 \\
\hline
\end{tabular}

Data dikatakan homogen atau mempunyai variasi kelompok yang sama, apabila nilai sig. hasil analisis $>0,05$. Tabel 4 . menunjukan data hasil pengujian homogenitas memperoleh nilai sig. jenis data pretest kemampuan pemecahan masalah pada kelas kontrol dan eksperimen sebesar 0,99. Nilai sig. 0,99 lebih tinggi dari 0,05, maka data mempunyai varian kelompok yang mirip atau homogen. Data posttest kemampuan pemecahan masalah pada kelas kontrol dan eksperimen sebesar 0,54. Nilai signifikasi 0,54 melebihi 0,05, sehingga disimpulkan data memiliki varian kelompok yang mirip atau homogen.

Data dikatakan memenuhi syarat untuk dilanjutkan pengujian hipotesis memakai pengujian independent t-test dan $\mathrm{N}$-Gain jika uji prasyarat terpenuhi. Pengujian independent t-test bertujuan untuk mengetahui ada atau tidaknya perbedaan rerata nilai posttest kelas eksperimen dan kontrol. Perolehan pengujian independent t-test dilakukan menggunakan SPSS 15 ditujukan pada tabel 5 .

Tabel 5. Hasil Pengujian Independent t-test

\begin{tabular}{cccc}
\hline Jenis Data Nilai & Nilai Sig. & $\boldsymbol{\alpha}$ & Keterangan \\
\hline Posttest & 0,000 & 0,05 & $\begin{array}{c}\mathrm{H}_{\mathrm{a}} \text { diterima } \\
\text { Ada perbedaan signifikan }\end{array}$ \\
\hline
\end{tabular}

Berdasarkan tabel 5 menunjukkan perolehan nilai signifikansi $0,000<0,05$, disimpulkan $\mathrm{H}_{\mathrm{a}}$ diterima. $\mathrm{H}_{\mathrm{a}}$ diterima mempunyai arti adanya perbedaan rerata nilai kemampuan pemecahan masalah kelas eksperimen dan kontrol yang signifikan. Sehingga dapat dikatakan, kemampuan peserta didik dalam memecahkan masalah pada kelas eksperimen yang menerapkan blended-problem based learning berbeda signifikan dengan kemampuan pemecahan masalah peserta didik di kelas kontrol yang menerapkan pendekatan saintifik (5M). Perbedaan yang signifikan berarti penerapan blended-problem based learning berhasil mengefektifkan peserta didik dalam pemecahan masalah bab ekologi kelas X di SMA N 5 Yogyakarta. Sesudah melakukan pengujian independent t-test, dilakukan pengujian uji N-Gain score untuk melihat peningkatan pemecahan masalah kelas kontrol dan eksperimen. Perhitungan N-Gain score dihitung melalui excle, diperoleh hasil yang ditunjukkan tabel 6.

Tabel 6. Hasil Pengujian N-Gain Score

\begin{tabular}{ccccc}
\hline \multirow{2}{*}{ Kelas } & \multicolumn{4}{c}{ Nilai N-Gain } \\
\cline { 2 - 5 } & Jumlah Peserta Didik & Minimum & Maximum & Rerata \\
\hline Eksperimen & 30 & 0,35 & 1 & 0,70 \\
\hline Kontrol & 28 & 0,06 & 0,63 & 0,298 \\
\hline
\end{tabular}


Tabel 7. Kategorisasi Nilai N-Gain Score

\begin{tabular}{cc}
\hline Rentan N-gain Score & Kategorisasi \\
\hline $0,00 \leq 3 \leq 0,3$ & Rendah \\
\hline $0,3 \leq 3 \leq 0,7$ & Sedang \\
\hline $0,7 \leq 3 \leq 1,00$ & Tinggi \\
\hline
\end{tabular}

Tabel 6 menunjukkan rerata nilai N-Gain pada kelas eksperimen 0,70 dan 0,298 untuk kelas kontrol. Berdasarkan kategorisasi rerata nilai $\mathrm{N}$-Gain Tabel 7, rerata nilai N-Gain eksperimen dikategorikan tinggi dan kelas kontrol dikategorikan rendah. Data dari rerata nilai N-Gain ini, menunjukkan bahwa blended-problem based learning yang diterapkan kelompok eksperimen mempunyai katerogi keefektifan yang lebih baik dari kelas kontrol. Gambar 2 menyajikan nilai pretest, posttest dan N-Gain.

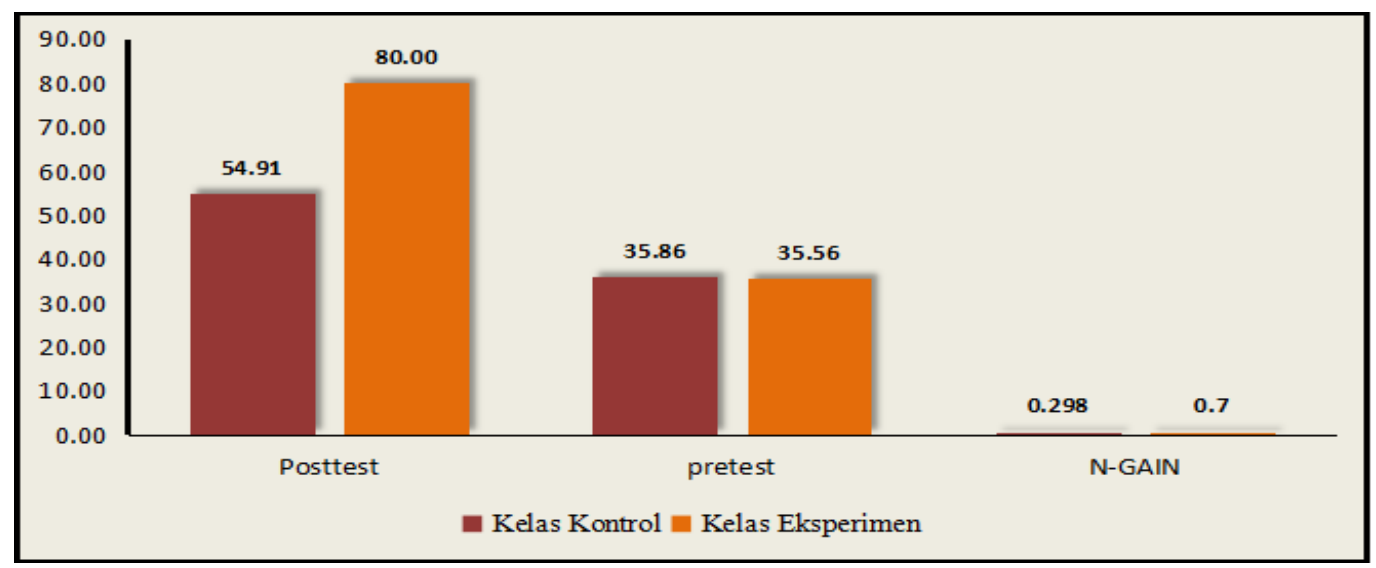

Gambar 2. Diagram Pretest, Posttest, dan N-Gain

\section{PEMBAHASAN}

Tujuan dari penelitian ini untuk melihat keefektifan blended-problem based learning pada pemecahan masalah dalam pembelajaran Biologi bab ekologi. Kelas yang digunakan pada penelitian ini terdiri dari dua kelas yaitu blended-problem based learning yang diterapkan dalam kelas eksperimen dan pendekatan santifik (5M) yang diterapkan di kelas kontrol. Untuk mengetahui keefektifan blended-problem based learning dilakukan pengujian hipotesis dari data penelitian berupa nilai pretest dan nilai posttest dari kelas kontrol dan eksperimen. Rerata nilai pretest tabel 1 dan gambar 1 kelas eksperimen dan kontrol menunjukkan hasil yang hampir mirip, ini berarti di kelas eksperimen maupun kontrol mempunyai kemampuan dalam memecahkan masalah bab materi ekologi yang hampir sama dan tergolong rendah. Masing-masing kelas diberi perlakuan sebanyak tiga pertemuan, di akhir pertemuan diberikan posttest. Perolehan nilai posttest lebih tinggi dari nilai pretest. Penyebab tingginya nilai posttest adalah dampak postif dari penerapan model pembelajaran di kelas eksperimen maupun kelas kontrol.

Hasil rerata nilai posttest kelas eksperimen dan kontrol terhadap kemampuan pemecahan masalah tabel 1 dan gambar 1. menunjukkan rerata nilai posttest kelas kontrol lebih rendah $(54,91)$ daripada kelas eksperimen yang memperoleh rerata nilai $(80,00)$. Perolehan tersebut, menunjukan kemampuan pemecahan masalah di kelas eksperimen setelah menerapkan blendedproblem based learning pada pembelajaran Biologi bab ekologi mengalami peningkatan yang signifikan. Jadi, implementasi blended-problem based learning pada pembelajaran Biologi bab ekologi memberikan suatu dampak positif dan kemampuan pemecahan masalah peserta didik mengalami peningkatan.

Hasil pengujian hipoteis 0,298 kategori rendah. Hasil analisis perhitungan N-Gain tersebut menunjukkan bahwa implementasi blended-problem based melalui uji independent $t$-test pada tabel 5 menunjukan adanya perbedaan signifikan antara rerata nilai kemampuan pemecahan masalah pada kelas eksperimen dan kontrol (nilai signifikansi $0,000<0,05$ ). keefektifan implementasi blended-problem based learning dalam pembelajaran Biologi bab ekologi terhadap kemampuan pemecahan masalah dan ditunjukan melalui hasil uji N-Gain dari kelas eksperimen dan kontrol. Hasil analisis perhitungan NGain tabel 7, kelas eksperimen 0,70 kategori tinggi dan kelas kontrol learning pada pembelajaran Biologi bab ekologi efektif dalam meningkatkan peserta didik untuk memecahkan masalah dan implementasi blended-problem based learning pada kelas eksperimen lebih efektif dibandingkan penerapan pendekatan saintifik (5M) pada kelas kontrol. 
Penerapan blended-problem based learning kelas eksperimen lebih efektif dari penerapan pendekatan saintifik (5M) di kelas kontrol dikarenakan blended-problem based learning mempunyai keunggulan yang tidak dimiliki pendekatan saintifik. Keunggunalan blended-problem based learning menjadi kekuatan sehingga ketika diterapkan pada kegiatan belajar-mengajar efektif dalam meningkatkan pemecahan masalah. Implementasi blended-problem based learning pada materi ekologi menggunakan teori belajar kontruktivisme yang mengharuskan peserta didik memahami dan menerapkan pengetahuan mengenai materi ekologi untuk menjawab permasalahan terkait materi ekologi yang telah disediakan oleh Guru. Guru dalam proses pembelajaran hanya sebagai fasilitator, jadi dalam proses pembelajarannya mengandalkan dari hasil dari usaha peserta didik itu sendiri bukan hanya mengandalkan dari Guru. Menurut (Sarita, 2017; Triyanto, Adi, \& Maya, 2014) menyatakan bahwa teori belajar kontruktivisme yaitu proses pembelajaran yang pengetahuannya dikembangkan secara aktif oleh peserta didik, tidak hanya menerima informasi secara pasif dan mentransformasikan pengetahuannya ke hal yang lebih kompleks. Penerapan blended-problem based learning yang menggunakan teori belajar kontruktivisme menjadi kekuatan dari blendedproblem based learning yang mampu menaikkan nilai kemampuan peserta didik dalam pemecahan masalah.

Penerapan blended-problem based learning dalam pembelajaran Biologi pada materi ekologi menggunakan sintaks PBL kemudian dari sintaks tersebut ada yang dilaksanakan melalui pembelajaran online dan ada yang dilaksanakan melalui pembelajaran tatap muka (face to face) di kelas. Dalam penerapannya, peserta didik setiap pertemuan diberikan permasalah ekologi sebagai stimulus untuk dipecahkan dan didiskusikan bersama dengan kelompoknya (orientasi masalah). Permasalahan tersebut diberikan saat pembelajaran online melalui Learning Management System (LMS) quipper school. Kemudian peserta didik melakukan diskusi online dengan kelompoknya untuk membahas masalah yang telah disajikan dan peserta didik diperbolehkan untuk mengakses internet untuk mencari informasi yang menunjang pemecahan masalah yang sedang didiskusikan. Diskusi online dapat dilakukan dimanapun dan kapanpun asalkan tidak melewati batas waktu yang ditentukan. Adanya penyajian permasalahan sebagai stimulus dalam pembelajaran online, diskusi online yang dipantau oleh guru, keleluasaan peserta didik memperoleh informasi dalam penerapan blended-problem based learning inilah yang mampu menaikkan kemampuan pemecahan masalah peserta didik dan menjadi kekuatan dari blended-problem based learning. Jadi, implementasi blended-problem based learning pada proses belajar-mengajar Biologi bab ekologi memberikan dampak positif terhadap peserta didik di kelas eksperimen. Ini sesuai dengan hasil penelitian Back et al (2014), menyatakan proses pembelajaran blended learning dengan problem based learning menciptakan dampak yang positif untuk peserta didik. Menurut Aeni, Prihatin, \& Utanto (2017); Stockwell, Cennamo, \& Jiang (2015), juga menyatakan bahwa blended learning dapat mendukung problem based learning yang secara signifikan mampu menaikkan kemampuan peserta didik dalam pemecahan masalah.

Diskusi online pada kegiatan belajar-mengajar online mememberikan rasa nyaman kepada peserta didik dalam menyampaikan pendapat atau mengomunikasikan ide-ide terkait pemecahan masalah yang dibahas dan dalam mempertimbangkan keputusan alternatif solusi yang diambil sehingga efektif untuk memecahkan masalah. Pernyataan tersebut sesuai dengan Sulaiman (2013) kegiatan belajar-mengajar berbasis masalah secara online efektif menaikkan kemampuan berpikir tingkat tinggi peserta didik. Dengan adanya diskusi online, peserta didik lebih memikirkan dan merenungkan ketika menyampaikan pendapat dibanding melalui komunikasi spontan pada kegiatan belajar-mengajar langsung di kelas. Pada kegiatan belajar-mengajar di kelas secara langsung, peserta didik diminta menyatukan pendapat-pendapat dari diskusi online dan mempresentasikannya. Kelompok yang tidak presentasi menanggapi. Akhir pembelajaran guru memberikan konfirmasi dan refleksi. Dengan menerapkan blended-problem based learning yang terjadi cenderung kegiatan belajar-mengajar langsung sebagai pelengkap dari pembelajaran online. Penelitian Dwi, Arif, \& Sentot (2013), menyatakan kemampuan pemecahan masalah peserta didik melalui pembelajaran masalah menggunakan ICT lebih tinggi daripada PBL tatap muka.

Hasil uji hipotesis penelitian ini melalui uji independent t-tes dan N-gain memperlihatkan penerapan blended-problem based learning pada kelas eksperimen lebih efektif dibandingkan penerapan pendekatan saintifik (5M) di kelas kontrol. Perolehan hasil penelitian ini sesuai dengan Sujanem, Jatmiko, \& Poedjiastoeti (2016), yang dalam penelitannya mengatakan model Pro-BHL efektif dalam menaikkan kemampuan pemecahan masalah peserta didik dilihat dari uji nilai N-Gain yang mengalami peningkatan signifikan. Penelitian Carrió, Larramona, Baños, \& Pérez (2011) dan Razzaq, Samiha, \& Anshari, (2018), mengungkapkan jika menggunakan kegiatan belajar-mengajar secara langsung yang dikombinasikan dengan teknologi pada pembelajaran online dan offline mampu menaikkan kemampuan akademik secara signifikan dibandingkan dengan kegiatan belajar mengajar secara langsung.

\section{SIMPULAN}

Penggunaan blended-problem based learning pada kegiatan belajar-mengajar Biologi bab ekologi di kelas eksperimen dan penggunaan pendekatan saintifik $(5 \mathrm{M})$ di kelas kontrol menunjukkan adanya perbedaan yang signifikan dari kedua perlakuan tersebut. Hal ini dibuktikan melalui hasil uji independent t-tes yang memperoleh nilai Sig $0,000<0,05$. Bukti lain dapat dilihat dari perolehan rerata nilai posttest kemampuan pemecahan masalah pada kelas eksperimen yang lebih besar dari rerata nilai posttest kemampuan pemecahan masalah di kelas kontrol. Padahal kemampuan awal peserta didik dalam 
memecahkan masalah di ke dua kelas tersebut hampir mirip. Penggunaan blended-problem based learning pada kegiatan belajar-mengajar Biologi pada materi ekologi terbukti lebih efektif dalam menaikkan kemampuan peserta didik dalam memecahkan suatu masalah. Dibuktikan dengan perolehan nilai N-gain di kelas eksperimen (penerapan blended-problem based learning) yang lebih besar dari peroleha nilai N-gain di kelas kontrol (saintifik), yaitu sebesar 0,70 berbanding 0,298.

Berdasarkan hasil dan pembahasan penelitian, menimbulkan beberapa saran yang dikemukakan oleh peneliti. Pertama, sebaiknya pada kegiatan belajar-mengajar Biologi Guru atau Pendidik menggunakan berbagai variasi model pembelajaran dan memakai teknologi sesuai dengan ketentuan pemerintah dalam kurikulum 2013. Kedua, Guru dapat menggunakan hasil penelitian ini dalam proses kegiatan belajar-mengajar Biologi untuk menaikkan kemampuan peserta didik dalam memecahkan suatu masalah untuk memenuhi ketentuan abad 21. Ketiga, Peneliti lain dapat mengembangkan penelitian menggenai penggunaan blended-problem based learning di mata pelajaran yang lain, materi yang lain, dan kemampuan kognitif peserta didik yang lain selain kemampuan pemecahan masalah.

\section{DAFTAR RUJUKAN}

Aeni, N., Prihatin, T., \& Utanto, Y. (2017). Pengembangan Model Blended Learning Berbasis Masalah pada Mata Pelajaran Sistem Komputer. Innovative Journal of Curriculum and Educational Technology, 6(2), 84-97. https://doi.org/10.15294/ijcet.v6i2.15642.

Al-Huneidi, A., \& Schreurs, J. (2013). Constructivism Based Blended Learning in Higher Education. International Journal of Emerging Technologies in Learning, 278(April 2016), 581-591. https://doi.org/10.1007/978-3-642-35879-1_74.

Aziz, M. S., Zain, A. N. M., Samsudin, M. A. Bin, \& Saleh, S. B. (2014). The Effects of Problem-Based Learning on SelfDirected Learning Skills among Physics Undergraduates. International Journal of Academic Research in Progressive Education and Development, 3(1), 126-137. https://doi.org/10.6007/ijarped/v3-i1/694.

Back, D. A., Haberstroh, N., Antolic, A., Sostmann, K., Schmidmaier, G., \& Hoff, E. (2014). Blended Learning Approach Improves Teaching in a Problem-Based Learning Environment in Orthopedics - A Pilot Study. BMC Medical Education, 14(1), 1-8. https://doi.org/10.1186/1472-6920-14-17.

Carrió, M., Larramona, P., Baños, J. E., \& Pérez, J. (2011). The Effectiveness of the Hybrid Problem-Based Learning Approach in the Teaching of Biology: A Comparison with Lecture-Based Learning. Journal of Biological Education, 45(4), 229235. https://doi.org/10.1080/00219266.2010.546011.

Delialioğlu, Ö. (2012). Student Engagement in Blended Learning Environments with Lecture-Based and Problem-Based Instructional Approaches. Educational Technology and Society, 15(3), 310-322.

Dwi, I. M., Arif, H., \& Sentot, K. (2013). Pengaruh Strategi Problem Based Learning Berbasis ICT terhadap Pemahaman Konsep dan Kemampuan Pemecahan Masalah Fisika. Jurnal Pendidikan Fisika Indonesia, 9(1), 8-17.

Etherington, M. B. (2011). Investigative Primary Science: A Problem-Based Learning Approach. Australian Journal of Teacher Education, 36(9), 36-57. https://doi.org/10.14221/ajte.2011v36n9.2.

Ghavifekr, S., \& Rosdy, W. A. W. (2016). Teaching and Learning with Technology: Effectiveness of ICT Integration in Schools. International Journal of Research in Education and Science, 1(2), 175. https://doi.org/10.21890/ijres.23596.

Ghazal, S., Aldowah, H., \& Umar, I. (2018). Critical Factors to Learning Management System Acceptance and Satisfaction in a Blended Learning Environment. Recent Trends in Information and Communication Technology, 5, 688-698. https://doi.org/10.1007/978-3-319-59427-9_71.

Gündüz, A. Y., Alemdağ, E., Yaşar, S., \& Erdem, M. (2016). Design of a Problem-Based Online Learning Environment and Evaluation of its Effectiveness. Turkish Online Journal of Educational Technology, 15(3), 49-57.

Holmes, K. A., \& Prieto-Rodriguez, E. (2018). Student and Staff Perceptions of a Learning Management System for Blended Learning in Teacher Education. Australian Journal of Teacher Education, 43(3), 21-34.

Isman, A., Abanmy, F. A. A., Hussein, H. B., \& Al Saadany, M. A. (2012). Using Blended Learning in Developing Student Teachers Teaching Skills. Turkish Online Journal of Educational Technology, 11(4), 336-345.

Ju, S. Y., \& Mei, S. Y. (2018). Perceptions and Practices of Blended Learning in Foreign Language Teaching at USIM. European Journal of Social Sciences Education and Research, 12(1), 170-176. https://doi.org/10.26417/ejser.v12i1.p170176.

Magdalena, O., Mulyani, S., \& Susanti, E. (2014). Pengaruh Pembelajaran Model Problem Based Learning dan Inquiry terhadap Prestasi Belajar Siswa ditinjau dari Kreativitas Verbal pada Materi Hukum Dasar Kimia. Jurnal Pendidikan Kimia, 3(4), 162-169.

Means, B., Toyama, Y., Murphy, R., \& Baki, M. (2013). Effectiveness of Online and Blended Learning. Teachers College Record, 115(30303), 1-47. https://doi.org/10.3991/ijac.v3i2.1322.

Pourshafie, T., \& Murray-Harvey, R. (2013). Facilitating Problem-Based Learning in Teacher Education: Getting the Challenge Right. Journal of Education for Teaching, 39(2), 169-180. https://doi.org/10.1080/02607476.2013.765190. 
Pulham, E., \& Graham, C. R. (2018). Comparing K-12 Online and Blended Teaching Competencies: A Literature Review. Distance Education, 39(3), 411-432. https://doi.org/10.1080/01587919.2018.1476840.

Ramakrisnan, P., Yahya, Y. B., Hasrol, M. N. H., \& Aziz, A. A. (2012). Blended Learning: A Suitable Framework for eLearning in Higher Education. Procedia - Social and Behavioral Sciences, 67, 513-526. https://doi.org/10.1016/j.sbspro.2012.11.356.

Razzaq, A., Samiha, Y. T., \& Anshari, M. (2018). Smartphone Habits and Behaviors in Supporting Students Self-Efficacy. International Journal of Emerging Technologies in Learning, 13(2), 94-109. https://doi.org/10.3991/ijet.v13i02.7685.

Sarita, P. (2017). Constructivism: A New Paradigm in Teaching and Learning. International Journal of Academic Research and Development, 2(4), 183-186.

Selvi, S. T., Kaleel, D., \& Chinnaiah, V. (2012). Applying Problem Based Learning Approach on E-Learning System in Cloud. International Conference on Recent Trends in Information Technologi, 244-249. https://doi.org/10.1109/ICRTIT.2012.6206814.

Şendağ, S., \& Odabaşi, F. H. (2009). Effects of an Online Problem Based Learning Course on Content Knowledge Acquisition and Critical Thinking Skills. Computers and Education, 53(1), 132-141. https://doi.org/10.1016/j.compedu.2009.01.008.

Smaldino, S. E., Lowther, D. L., \& Mims, C. (2012). Instructional Technology and Media for Learning (12th ed.). https://doi.org/10.1016/J.ARABJC.2011.11.008.

Stockwell, B. R., Stockwell, M. S., Cennamo, M., \& Jiang, E. (2015). Blended Learning Improves Science Education. Cell, 162(5), 933-936. https://doi.org/10.1016/j.cell.2015.08.009.

Sujanem, R., Jatmiko, B., \& Poedjiastoeti, S. (2016). Efektivitas Model PRO-BHL dalam Meningkatkan Kemampuan Pemecahan Masalah Fisika Siswa SMA. Prosiding Seminar Nasional MIPA 2016, 120-126.

Sulaiman, F. (2013). The Effectiveness of PBL Online on Physics Students' Creativity and Critical Thinking: A Case Study at Universiti Malaysia Sabah. International Journal of Education and Research, 1(3), 1-18.

Suryani, N. (2013). Improving Quality of Learning at University Through Application of Blended Learning: A Case Study at Sebelas Maret University, Solo, Indonesia. International Journal of Education and Research, 1(6), 1-12.

Torres-Gastelú, C. A., Dominguez, A. L., García, M. A. F., Kiss, G., \& Espinoza, A. R. A. (2015). Student's Perception about Online Interaction, Access and Publishing Content for Academic Use. Turkish Online Journal of Educational Technology, 14(3), 138-144.

Triyanto, S. A., Adi, B., \& Maya, R. (2014). Penerapan Model Pembelajaran Blended-Problem Solving melalui Aplikasi Moodle untuk Meningkatkan Kemampuan Berpikir Kritis Siswa Kelas X-1 SMA N 3 Surakarta Tahun Pelajaran 2012/2013. Bio-Pedagogi, 3, 99-108.

Yeh, Y. (2010). Integrating Collaborative PBL with Blended Learning to Explore Preservice Teachers' Development of Online Learning Communities. Teaching and Teacher Education, 26(8), 1630-1640. https://doi.org/10.1016/j.tate.2010.06.014. 